Subsequent follow-up (during the first year of life) showed that in children of the main group were less frequently detected functional disorders of the gastrointestinal tract $(15.8 \%$ vs $36.5 \%, \mathrm{P}=0.034)$ and allergic diseases $(1.2 \%$ vs $5.8 \%, \mathrm{P}=0.056)$.

In newborns whose mothers received a probiotic during the 6 weeks before delivery, after birth levels of both markers of intestinal inflammation (fecal eosinophil-derived protein and fecal calprotectin) were significantly lower than in comparison group (children whose mothers not used probiotics).

In addition, in children of the main group in the first year of life were less than half detected such conditions as functional disorders of the gastrointestinal tract and manifestations of food allergies.

\section{EARLY NEONATAL OUTCOME OF NEWBORNS WITH MOTHERS HYPOTHYREOSIS IN PREGNANCY}

Diana Milas*, Gordana Lukić, Tihana Nað, Andrea Prutki. OŽB VUKOVAR, Medicinski fakultet Osijek

\subsection{6/archdischild-2021-europaediatrics. 112}

Newborns of mothers with hypothyroidism (latent or manifest) in pregnancy were investigated during two one-year periods. The aim was to point out particularities in mother's anamnesis, pregnancy and labour, as well as the clinical characteristics of neonates (Apgar score, gestational age, birth weight, mode of delivery) and to compare the differences in two periods.

Subjects The research was conducted on newborns of mothers with hypothyroidism in pregnancy in the Clinical Hospital Centre Osijek in 2015 and 2018. The control group consisted of newborns first born afterwards.

The data were presented in tables, in absolute and relative frequencies.

Chi-square test was used to demonstrate the statistical significance, resulting in significance level of $\mathrm{p}<0.05$. It was retrospective case control study.

Mothers with hypothyroidism in pregnancy had more acute complications in pregnancy (infections, hypertension, preeclampsia, gestational diabetes) and delivery, and more complications in reproductive anamneses. Urgent Caesarean section was much more common for their newborns. C-reactive protein among them was often higher than $5 \mathrm{mg} / \mathrm{l}$. They gave birth prematurely more often, while infections, cyanosis, hypoand hypertonus, and jaundice were also more common. Complications of prematurity and the need for oxygenation occurred much more often than in the control group. They were also hospitalized longer. Comparing the two one-year periods, we found less complications during pregnancy and delivery in the year 2018; the frequency of mothers with bad reproductive anamnesis was three times lower, as was the number of urgent Caesarean sections. The number of newborns born prematurely was two times smaller. In 2018, neonatal outcome included three times less common onset of infection, cyanosis, hypo- and hypertonus, and less common preterm labour. The need for oxygenation was five times, and for prolonged hospitalisation nine times less common.

Conclusion Better perinatal care and screening of mothers with hypothyroidism improves neonatal outcome as well as long-life consequences in newborns and lowers the complication rates for mothers during pregnancy and delivery.

\section{UMBILICAL CORD BLOOD CYTOKINES TNF $\alpha$ AND IFN $\gamma$ LEVELS INCREASED IN CHILDREN BORN TO MOTHERS WHO ARE OBESE}

${ }^{1}$ VP Novikova*, ${ }^{1} Y u$ V Petrenko, 'DO Ivanov, ${ }^{1}$ NE Prokopyeva, ${ }^{1} O P$ Gurina, ${ }^{1}$ AE Blinov, ${ }^{1}$ ON Varlamova, ${ }^{2}$ TV Kosenkova, ${ }^{2}$ EA Boytsova. 'Saint-Petersburg State Pediatric Medical University; ${ }^{2}$ Federal State Budgetary Institution «V.A. Almazov National Medical Research Center» of the Ministry of Health of the Russian Federation, Saint-Petersburg

\subsection{6/archdischild-2021-europaediatrics. 113}

Introduction Maternal obesity is considered one of the several key factors that affect development of the immune system of newborns. Experimental and clinical data indicate an increased risk of developing autoimmune, allergic diseases and obesity in the offspring of obese mothers. The main mechanisms of the relationship between mother's body weight and the immune system of a newborn person remain poorly understood.

Objectives Aim of this study was to analyze the cytokine status of umbilical cord blood of children born to mothers with obesity.

Methods Umbilical cord blood samples were taken from 65 children born to thin $(\mathrm{n}=24)$, with overweight $(\mathrm{n}=9)$ and obese mothers $(\mathrm{n}=32$ ). The levels of TNF $\alpha$, TGF $\beta 1$, IL 18, IL 13, IL10 and IFN $\gamma$ were quantified by IFA. Statistical processing of data was performed on a personal computer using licensed computer software 'Microsoft Excel 2016' and 'STATISTICA 12'. The Student t-test value was determined while analyzing the distribution of quantitative data. The criterion of statistical significance level was $\mathrm{p}<0.05$.

Results Compared to children born to thin mothers, children born to obese mothers had higher levels of umbilical cord blood plasma TNF $\alpha(12,75 \pm 10,80 \mathrm{pg} / \mathrm{ml}$ and 4,94 $\pm 3,55 \mathrm{pg} /$ $\mathrm{ml} ; \mathrm{P} 1,3=0,005408)$ and IFN $\gamma(798,90 \pm 565,96 \mathrm{pg} / \mathrm{ml}$ and 311,05 $\pm 249,08 \mathrm{pg} / \mathrm{ml} ; \mathrm{P} 1,3=0,014947$ ).

Conclusion These results confirm the hypothesis that maternal obesity affects programming of the immune system of newborns providing a potential connection with an increase in the incidence of chronic inflammatory diseases and obesity in offspring.

\section{HYPOTHERMIA IS PREVENTABLE}

L Collins*, J Wood, A Faire, G Kakade, S Barrett, F Patel, Deepa Panjwani, S Rao. East Suffolk and North Essex NHS Trust Colchester Hospital

\subsection{6/archdischild-2021-europaediatrics. 114}

Background Temperature regulation is an important part of new-born care.

This is especially true of pre-term infant and those with the low-birth weight, which represent a significant proportion of the population in the neonatal unit.

Aim The audit was performed to assess the quality of care in relation of hypothermia. The audit was aimed at observing babies admitted to neonatal unit Leicester Royal Infirmary and Leicester General during the months of June -July (period 1) and November - December (period 2), with a body temperature below the 36.5. The second objective was to look at the documentation of the admission temperature

Methods The data was collected retrospectively. Babies were identify using the online record system. Data was also collected on gestational age, birth weight, reason for admission 